\title{
Pengaruh Sosialisasi Diagram Pareto terhadap Pengetahuan dan Minat Perawat dalam Pengelolaan Bahan Habis Pakai
}

\author{
Urip Pratama ${ }^{1}$, Nurmaini ${ }^{2}$, Roymond Halomoan Simamora ${ }^{3}$ \\ 1Program Magister, Fakultas Keperawatan, Universitas Sumatera Utara \\ ${ }^{2}$ Fakultas Kesehatan Masyarakat, Universitas Sumatera Utara \\ ${ }^{3}$ Fakultas Keperawatan, Universitas Sumatera Utara \\ bulanpatah22@gmail.com¹, nurmaini@usu.ac.id², roymond_oy@yahoo.com³
}

Diajukan 30 Oktober 2020 Diperbaiki 30 Desember 2020 Diterima 5 Januari 2021

\section{ABSTRAK}

Latar Belakang: Diagram Pareto merupakan salah satu alat ukur mutu untuk menganalisis pengelolaan bahan habis pakai sehingga menjadi hal penting bagi rumah sakit. Hal ini dipengaruhi juga dengan pengetahuan dan minat perawat yang rendah, bukan hanya karena fasilitas yang tidak memadai tetapi karena pengaruh minimnya informasi tentang pentingnya pengelolaan bahan habis pakai tersebut.

Tujuan: Mengetahui pengaruh sosialisasi diagram Pareto terhadap pengetahuan dan minat perawat dalam pengelolaan bahan habis pakai.

Metode: Metode eksperimen semu dengan pre-posttest dengan kelompok kontrol. Sampel penelitian 100 perawat pelaksana di Rumah Sakit Daerah Provinsi Aceh, yang dibagi menjadi kelompok intervensi $(n=50)$ dan kelompok kontrol $(n=50)$, dengan menggunakan teknik consecutive sampling. Pengetahuan perawat diukur menggunakan lembar observasi dan kuesioner penggunaan diagram Pareto, Microsoft Excel Format 2 Axis dan klasifikasi bahan habis pakai, sedangkan minat perawat diukur dengan menggunakan lembar observasi, kemudian data diuji dengan Correlation Pearson Test.

Hasil: Setelah intervensi, peningkatan pengetahuan perawat dari kategori sedang $(n=12,24.0 \%)$ menjadi tinggi $(n=25,50.0 \%)$ dan peningkatan minat perawat dari kategori sedang $(n=13,26.0 \%)$ menjadi tinggi $(n=27,54.0 \%)$.

Kesimpulan: Sosialisasi diagram Pareto berpengaruh meningkatkan pengetahuan $p$-value $=0.027$ $(\mathrm{p}<0.05)$ dan minat perawat $p$-value $=0.030(\mathrm{p}<0.05)$ dalam pengelolaan bahan habis pakai di rumah sakit.

Kata Kunci: sosialisasi; diagram pareto; bahan habis pakai

\section{ABSTRACT}

Background: The Pareto diagram is a quality measurement tool for analyzing the management of consumables so that it becomes important for hospitals. This is also influenced by the low knowledge and interest of nurses, not only because of inadequate facilities but also because of the influence of the lack of information on the importance of managing these consumables.

Objective: To determine the effect of Pareto chart dissemination on nurses' knowledge and interest in the management of consumables.

Method: A quasi-experimental method with pre-post test with the control group. The research sample of 100 nurses at the regional hospital in Aceh province was divided into the intervention group $(n=50)$ and the control group ( $n=50)$, using consecutive sampling technique. Nurses 'knowledge was measured using observation sheets and a questionnaire using Pareto diagrams, Microsoft Excel Format 2 Axis, and classification of consumables, while nurses' interest was measured using observation sheets.

Results: After the intervention, there was an increase in the knowledge of nurses from the moderate category ( $n$ $=12,24.0 \%)$ to high $(n=25,50.0 \%)$ and the increase in nurse interest from the moderate category $(n=13$, $26.0 \%)$ to high $(n=27,54.0 \%)$.

Conclusion: Pareto diagram dissemination has the effect of increasing knowledge of $p$-value $=0.027(p<0.05)$ and nurse interest $p$-value $=0.030(p<0.05)$ in the management of consumables in hospitals.

Keywords: dissemination; pareto diagram; consumables 
Pengaruh Sosialisasi Diagram Pareto terhadap Pengetahuan...

PENDAHULUAN

Perkembangan dalam dunia kesehatan secara global berpengaruh juga pada perusahaan di sektor barang maupun jasa (Balasubramanian, 2016). Guna menghadapinya, perusahaan tersebut dituntut untuk memiliki kekuatan atau daya saing, salah satunya di bidang logistik (Dahlgaard et al., 2011), yaitu cara memperbaiki pengelolaan bahan habis pakai (El-Tohamy \& Raoush, 2015). Hal ini dikarenakan bahwa alat medis yang masuk dari sektor manajemen logistik akan semakin menumpuk dan tidak dikelola dengan baik ketika tenaga medis tidak dibekali ilmu pengetahuan dalam pengelolaan bahan habis pakai (Liu et al., 2016).

Perawat adalah tenaga kesehatan yang lebih sering menggunakan alat-alat medis. Oleh sebab itu, mereka harus mengetahui siklus dalam pengelolaan bahan habis pakai, yakni perencanaan, pengadaan, penerimaan, pengendalian, pencatatan, dan pelaporan, yang termasuk dalam rencana sebuah ruangan (Alolayyan et al., 2011). Hal tersebut berguna untuk mengetahui apakah alat medis tersebut berkurang, habis, atau bahkan alat medis yang menjadi prioritas utama dalam sebuah ruang perawatan (Sweis et al., 2013).

Terdapat beberapa faktor penghambat pengetahuan perawat dalam mengelola bahan habis pakai, di antaranya umur, lingkungan, latar belakang pendidikan, dan pengalaman (Chang et al., 2013). Sebagai tambahan, faktor-faktor yang menghalangi minat perawat dalam mengelola bahan habis pakai adalah rendahnya rasa ingin tahu, kurangnya kesadaran, kurangnya informasi, fasilititas yang kurang memadai, dan padatnya jadwal pekerjaan (Parand et al., 2014).

Diagram Pareto merupakan konsep evolusi baru yang berakar dari gaya manajemen modern, yang telah diterapkan di berbagai negara maju
(Rabou et al., 2017). Diagram ini membantu menganalisis bahan habis pakai yang digunakan oleh rumah sakit (RS) melalui pendekatan kolaboratif dan standar kinerja (Furterer, 2014).

Sebagai bahan yang ditujukan untuk sekali pakai, daftar produk bahan ini harus diatur dalam peraturan perundangundangan (Jiang \& Zhou, 2012). Pengelolaan bahan seperti sediaan farmasi, alat kesehatan, dan bahan habis pakai harus dilaksanakan secara multidisiplin, terkoordinir, dan menggunakan proses yang efektif untuk menjamin kendali mutu dan kendali biaya (Lin et al., 2010). Bahan habis pakai bersifat siklik, yaitu sebuah siklus kegiatan yang dimulai dari perencanaan, penerimaan, pengendalian, pencatatan, dan pelaporan. Hal ini harus dikuasai oleh perawat sebagai tenaga kesehatan yang paling banyak menggunakan alat kesehatan. Konsekuensinya, pihak manajemen mutu selayaknya memberikan pelatihan atau minimal sosialisasi untuk meningkatkan pengetahuan dan minat perawat untuk melaksanakan pelayanan logistik di RS (Zhang et al., 2013).

Menurut laporan penelitian yang dilakukan oleh Yang et al. (2019), kejadian kegagalan pengelolaan bahan habis pakai di RS sebanyak 1.324 kasus, yang diidentifikasi sekitar $60 \%$ disebabkan oleh masalah kurangnya pengetahuan dalam penanganan pengelolaan bahan habis pakai. Di penelitian lainnya, menurut Yang et al. (2016), ada sekitar 47\% masalah kegagalan pengelolaan alat medis habis pakai setiap tahunnya dikarenakan kurangnya minat petugas dalam menganalisis bahan habis pakai. Hal ini dikuatkan lagi dengan data penggunaan alat medis habis pakai di Asia Tenggara yang dikutip dari Ahmad et al. (2017), yaitu bahwa angka kejadian kegagalan dalam pengelolaan bahan habis pakai pada suatu perusahaan barang dan jasa sebanyak 73\%, bukti kurangnya pengetahuan dalam pengelolaan bahan 
habis pakai menggunakan alat ukur mutu sebesar 43-55\%, dan kurangnya minat perawat dalam mengelola bahan habis pakai hingga mengakibatkan pembengkakan tagihan pasien sebesar $39 \%$.

Di Indonesia, melalui Administrasi Rumah Sakit Indonesia (ARSI) yang dikutip dari Manurung (2017), kegagalan pengelolaan bahan habis pakai menduduki peringkat pertama dalam hal pengelolaan logistik $(48,8 \%)$ dari 10 besar kejadian yang dilaporkan. Kurangnya pengetahuan petugas yang ada di ruangan dalam penempatan dokumen, kurangnya pengetahuan dalam hal penanganan obat di dalam wadah khusus, kurangnya minat petugas dalam hal menyusun barang lain yang tidak diperlukan di lemari, adanya obat kadaluarsa ditemukan, kurangnya pengetahuan dan minat petugas dalam hal pencatatan jumlah item dengan kartu stok disebabkan utamanya oleh manajemen yang tidak memberikan sosialisasi atau pelatihan tentang pengelolaan bahan habis pakai sehingga tenaga kesehatan (nakes) tidak tahu apa bahan habis pakai dan bagaimana mengelolanya, dan nakes berpikir bahwa mengelola barang habis pakai bukanlah pekerjaan mereka.

Persentase prevalensi RS di Indonesia yang mengelola bahan habis pakai dengan alat kendali mutu sebanyak $(42,4 \%)$, yang meliputi staf manajemen mutu, manajemen logistik, dan manajemen perawat (Ismariati et al., 2017). Hal senada juga juga dijelaskan oleh Hani et al. (2013) bahwa sebanyak 37,8\% dari jumlah RS yang ada melakukan pelatihan pengelolan bahan habis pakai secara berkala sebagai salah satu alat ukur mutu.

Keuntungan penerapan diagram Pareto dalam pengelolaan bahan habis pakai di suatu perusahaan, baik barang maupun jasa, dapat diketahui bahwa persentase kerusakan barang dan peralatan $48 \%$ disebabkan oleh bahan baku yang tidak sesuai dengan prosedur pemakaian, teknik penggunaan, posisi yang salah, dan personel yang kurang terampil dalam menggunakan alat dan bahan. Selain itu, setelah diagram pareto diterapkan, hal tersebut mengalami penurunan yang signifikan yakni $22 \%$ dari sebelum penerapan diagram Pareto dalam pengelolaan bahan habis pakai (Ahmed \& Ahmad, 2011).

Untuk persentase sosialisasi atau pelatihan yang dilakukan secara berkala akan memberikan dorongan minat dan pengetahuan seseorang dalam hal melakukan kegiatan pengelolaan alat medis habis pakai sebesar 33\%, karena spesifikasi bahan yang tidak tepat, posisi yang tidak tepat, dan teknik penggunaan yang salah. Hal tersebut juga mengalami penurunan yang cukup signifikan yakni $17 \%$ dari sebelumnya yang tidak dilakukan sosialisasi atau pelatihan diagram Pareto dalam menganalisis bahan habis pakai (Belkasseh, 2019). Persentase penggunaan alat terbuang percuma di dalam ruangan sebesar $49 \%$ karena spesifikasi karyawan yang kurang terampil, penggunaan alat yang tidak tepat, dan penggunaan yang kurang tepat antara alat dan pengguna. Kejadian tesebut juga mengalami penurunan yang sangat signifikan yakni sebesar $24 \%$ dari perawat sebelumnya yang tidak dibekali pemahaman tentang pengelolaan bahan habis pakai menggunakan diagram Pareto (Al-Shdaifat, 2015).

Berdasarkan data penggunaan alat kesehatan habis pakai dan petugas yang telah melakukan pelatihan penggunaan alat ukur mutu di Rumah Sakit Umum Daerah (RSUD) Kabupaten Simeulue, Provinsi Aceh, dari 47 tenaga manajemen mutu, 35 staf manajemen logistik, dan 186 perawat yang telah bekerja lebih dari 1 tahun, mereka yang telah berpengalaman dalam mengelola bahan habis pakai dengan menggunakan salah satu alat ukur kualitas, staf manajemen mutu sebanyak 9 orang $(19,15 \%)$, staf manajemen logistik 15 
orang $(42,8) \%)$, dan 22 perawat $(11.832 \%)$ (Budhiarta \& Samuthi, 2019).

Oleh sebab itu, berdasarkan studi penelitian terdahulu dan data survei awal yang telah dijelaskan di atas, maka perlu sebuah metode atau alat untuk menganalisis keperluan dan kegunaan bahan habis pakai yang ada di ruang perawatan. Pihak manajemen mutu dan logistik rumah sakit harus dapat mengoptimalkan peran mereka dalam memberikan sosialisasi, terutama tentang perkembangan kemajuan teknologi dalam mengelola bahan habis pakai.

Penelitian ini bertujuan untuk mengetahui ada tidaknya pengaruh sosialisasi diagram Pareto terhadap pengetahuan dan minat perawat dalam pengelolaan bahan habis pakai.

\section{METODE}

Penelitian ini merupakan penelitian eksperimen semu, dengan pre-test dan post-test untuk kelompok intervensi dan kelompok kontrol. Penelitian ini dilakukan di Rumah Sakit Umum Daerah (RSUD) Kabupaten Simeulue Provinsi Aceh pada bulan Agustus 2019. Seratus perawat dijadikan sebagai responden dengan menggunakan teknik consecutive sampling. Kriteria inklusi dalam penelitian ini adalah bersedia menjadi responden dibuktikan dengan mengisi informed consent, responden minimal lulusan diploma tiga keperawatan, pegawai negeri sipil, pegawai honorer, dan tenaga sukarela, serta berpengalaman kerja lebih dari satu tahun. Kriteria eksklusi dalam penelitian ini adalah staf perawat bidang keperawatan, staf perawat bidang logistik, dan staf perawat bidang manajemen mutu.

Penelitian ini menerapkan intervensi berupa penyuluhan diagram Pareto kepada perawat pelaksana yang dilakukan satu bulan penuh. Pre-test pada penelitian ini dilakukan pada minggu pertama dengan penyebaran kuesioner dan pembagian modul penelitian. Pada minggu kedua dan ketiga, peneliti memberikan sosialisasi berupa materi tahap-tahap pembuatan diagram Pareto dengan menggunakan Microsoft Excel format 2 Axis. Sosialisasi ini berisi tentang keuntungan dan kemudahan menggunakan diagram Pareto dalam mengelola bahan habis pakai, yang diharapkan memberikan peningkatan pengetahuan dan minat perawat setelah diberikan sosialisasi.

Penelitian ini terbagi dalam beberapa tahapan. Tahap persiapan yang dilakukan pada minggu pertama terdiri dari observasi, pengisian kuesioner tahap awal, kemudian tahap pelaksanaan yang dilakukan pada minggu kedua dan ketiga terdiri dari pembagian modul langkahlangkah pembuatan diagram Pareto, sosialisasi diagram Pareto dalam pengelolaan bahan habis pakai yang terdiri dari 40 menit sosialisasi dan 20 menit tanya jawab.

Pada tahap pre-test atau tahap evaluasi dilakukan pada minggu keempat, yang terdiri dari pengisian kuesioner tahap akhir dan evaluasi pemahaman perawat terhadap pengelolaan bahan habis pakai dengan menggunakan diagram Pareto. Pengetahuan perawat diukur dengan menggunakan kuesioner dan lembar observasi, sedangkan minat perawat diukur dengan menggunakan lembar observasi. Kuesioner yang digunakan pada penelitian ini adalah penggunaan bagan Pareto dengan menggunakan Microsoft Excel Format 2 Axis dan klasifikasi bahan habis pakai. Tes ini memiliki skor 1 hingga 3, untuk masing-masing kategori. Skor 1 menunjukkan pemahaman yang rendah, skor 2 menunjukkan pemahaman yang sedang dan skor 3 menunjukkan pemahaman yang tinggi.

Lembar observasi untuk mengetahui pengetahuan perawat adalah alat yang digunakan untuk mengamati pelaksanaan intervensi sosialisasi diagram Pareto menggunakan Microsoft Excel Format 2 
Axis. Berdasarkan protokol yang telah dibuat, peneliti menggunakan tanda Checklist $(\sqrt{ })$ jika menemukan responden yang telah mengetahui langkah-langkah pembuatan diagram Pareto dalam mengelola bahan habis pakai, dan jika peneliti mengamati responden belum mengetahui adanya pembuatan langkahlangkah diagram Pareto dalam mengelola bahan habis pakai, maka akan diberi tanda (X). Hasil akhir dari penelitian ini ditandai dengan minat perawat dalam menerapkan bahan habis pakai dengan menggunakan diagram Pareto di tiap-tiap ruangan yang mereka tempati.

Analisis bivariat dalam penelitian ini menggunakan Correlation Pearson Test. Tes ini untuk mengetahui perbedaan skor pengetahuan dan minat perawat pada kelompok intervensi dan kelompok kontrol sebelum dan sesudah dilakukan intervensi sosialisasi diagram Pareto.

Kerangka konseptual pada peneltian ini dapat dilihat pada gambar 1 .

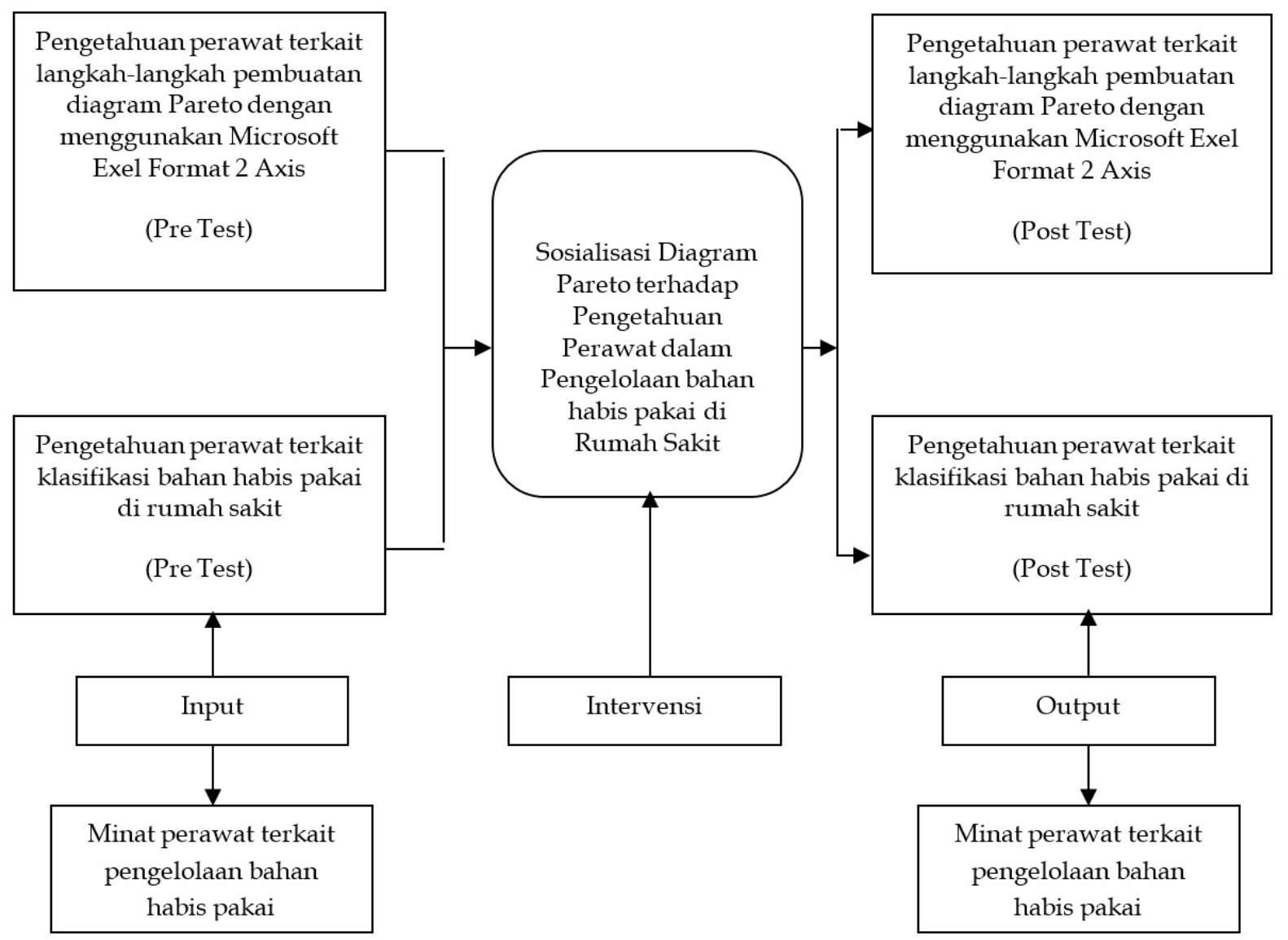

Gambar 1. Kerangka Konseptual

\section{HASIL DAN PEMBAHASAN}

\section{A. Hasil Penelitian}

\section{Karakteristik Demografi Responden}

Hasil penelitian dari distribusi frekuensi dan persentase karakteristik responden menunjukkan bahwa data karakteristik responden menggambarkan mayoritas perawat umur 31-35 tahun ( $\mathrm{n}=19$ tahun, 38.3\%), jumlah responden berdasarkan jenis kelamin mayoritas perempuan ( $\mathrm{n}=28$ perawat, $56.0 \%$ ), jumlah responden berdasarkan latar belakang pendidikan mayoritas Diploma Tiga Keperawatan (D3) (n=33 perawat, 66.0\%), sedangkan jumlah responden berdasarkan lamanya berkerja mayoritas 7-10 tahun $(\mathrm{n}=15$ perawat, $30.0 \%$ ) dan jumlah responden berdasarkan status pekerjaan perawat mayoritas pegawai negeri sipil $(\mathrm{n}=24$ perawat, $48.0 \%)$. Distribusi frekuensi dan karakteristik responden dapat dilihat pada tabel sebagai berikut 
Pengaruh Sosialisasi Diagram Pareto terhadap Pengetahuan...

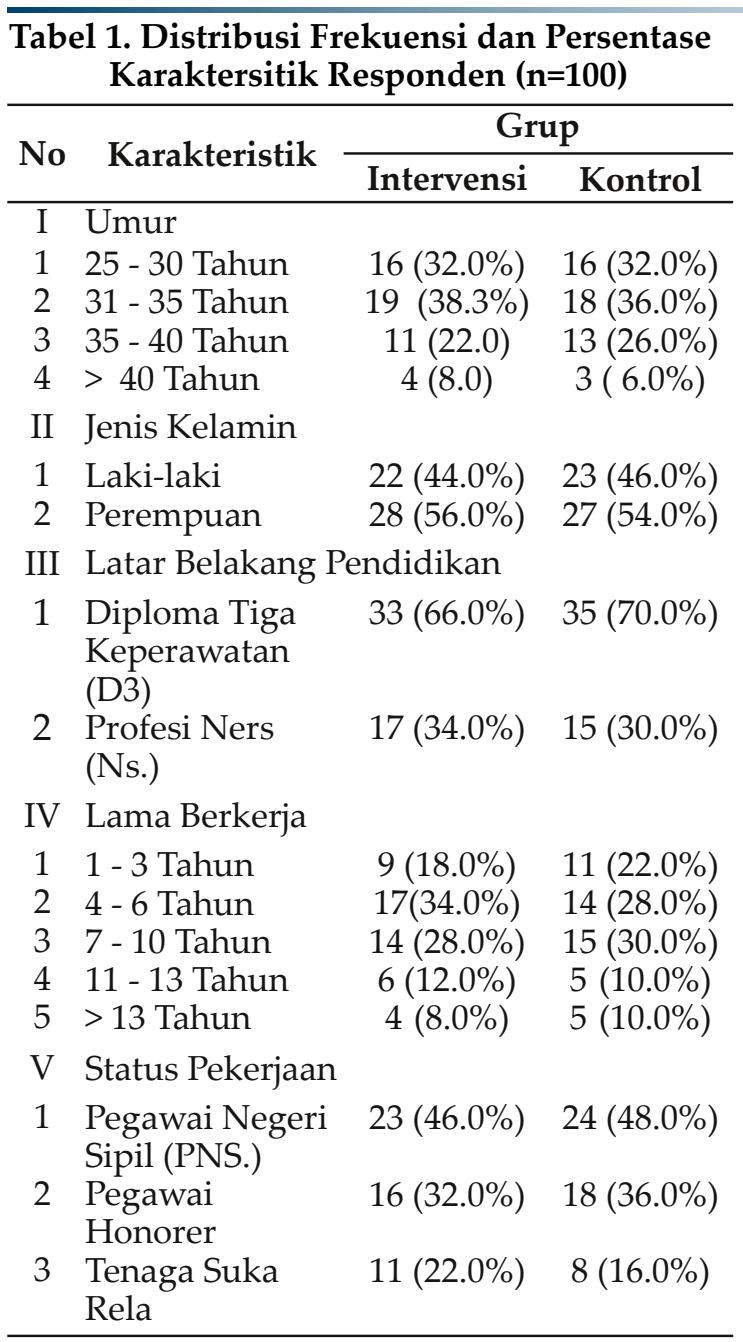

Hasil Pengukuran Tingkat Pengetahuan Perawat Dalam Pengelolaan Bahan Habis Pakai Sebelum dan Sesudah Diberikan Sosialisasi Diagram Pareto

Hasil pengukuran tingkat pengetahuan perawat dalam pengelolaan bahan habis pakai sebelum dilakukan intervensi tertera pada tabel 2 .

Tabel 2. Distribusi Frekuensi Tingkat Pengetahuan Perawat Tentang Pengelolaan Bahan Habis Pakai Sebelum dan Sesudah Intervensi $(\mathrm{n}=\mathbf{1 0 0})$

\begin{tabular}{|c|c|c|c|c|c|}
\hline \multirow[b]{2}{*}{ No. } & \multirow{2}{*}{$\begin{array}{l}\text { Pengeta } \\
\text { huan }\end{array}$} & \multicolumn{2}{|c|}{ Intervensi } & \multicolumn{2}{|c|}{ Kontrol } \\
\hline & & $\begin{array}{c}\text { Sebelu } \\
\text { m }\end{array}$ & & $\begin{array}{c}\text { Sebelu } \\
\text { m }\end{array}$ & C \\
\hline 1 & & $\begin{array}{c}9 \\
(18.0 \%)\end{array}$ & $\begin{array}{c}25 \\
(50.0 \%)\end{array}$ & $\begin{array}{c}8 \\
(16.0 \%)\end{array}$ & $\begin{array}{r}8 \\
(16.0\end{array}$ \\
\hline 2 & & $\begin{array}{c}12 \\
(24.0 \%)\end{array}$ & $\begin{array}{c}19 \\
(38.0 \%)\end{array}$ & $\begin{array}{c}13 \\
(26.0 \%)\end{array}$ & $\begin{array}{c}12 \\
(24.0 \%)\end{array}$ \\
\hline 3 & Ren & $\begin{array}{c}29 \\
(58.0 \%)\end{array}$ & $\begin{array}{c}6 \\
(12.0 \%)\end{array}$ & $\begin{array}{c}29 \\
(58.0 \%)\end{array}$ & $\begin{array}{c}30 \\
(60.0 \%)\end{array}$ \\
\hline
\end{tabular}

Tabel 2 di atas menunjukkan peningkatan pengetahuan perawat pasca sosialisasi, dari kategori sedang $(n=12$,
$24.0 \%)$ menjadi tinggi $(\mathrm{n}=25,50.0 \%)$.

Hasil Pengukuran Sosialisasi Diagram Pareto Dalam Peningkatan Pengetahuan Perawat Terhadap Pengelolaan Bahan Habis Pakai

Hasil pengukuran sosialisasi Pareto terhadap pengetahuan perawat dalam pengelolaan bahan habis pakai tersaji pada tabel 3.

Tabel 3. Pengaruh Sosialisasi Diagram Pareto Dalam Peningkatan Pengetahuan Perawat Terhadap Pengelolaan Bahan Habis Pakai

\begin{tabular}{clccc}
\hline No. & Grup & Mean & SD & p-value \\
\hline 1 & Intervensi & 1.32 & 0.513 & \multirow{2}{*}{0.027} \\
2 & Kontrol & 2.44 & 0.760 & \\
\hline
\end{tabular}

Pada tabel 3 di atas, hasil uji statistik dengan Correlation Pearson menunjukkan bahwa sosialisasi bagan Pareto berpengaruh dalam meningkatkan pengetahuan perawat tentang pengelolaan bahan habis pakai di Rumah Sakit Simeulue dengan nilai $p$-value $=$ 0.027 ( $p$-value $<0.05$ ).

\section{Hasil Pengukuran Minat Perawat Dalam Pengelolaan Bahan Habis Pakai Sebelum dan Sesudah Diberikan Sosialisasi Diagram Pareto}

Hasil pengukuran minat perawat dalam pengelolaan bahan habis pakai sebelum dilakukan intervensi tertera pada tabel 4.

Tabel 4. Distribusi Frekuensi Minat Perawat Tentang Pengelolaan Bahan Habis Pakai Sebelum dan Sesudah Intervensi $(n=100)$

\begin{tabular}{|c|c|c|c|c|c|}
\hline \multirow[b]{2}{*}{ No. } & \multirow[b]{2}{*}{$\begin{array}{c}\text { Pengeta } \\
\text { huan }\end{array}$} & \multicolumn{2}{|c|}{ Intervensi } & \multicolumn{2}{|c|}{ Kontrol } \\
\hline & & $\begin{array}{c}\text { Sebelu } \\
\text { m }\end{array}$ & Se & $\begin{array}{c}\text { Sebelu } \\
\text { m }\end{array}$ & \\
\hline 1 & & $\begin{array}{c}11 \\
(22.0 \%)\end{array}$ & $\begin{array}{c}27 \\
(54.0)\end{array}$ & $\begin{array}{c}7 \\
(14.0 \%)\end{array}$ & $\begin{array}{c}6 \\
(12.0 \%)\end{array}$ \\
\hline 2 & & $\begin{array}{c}13 \\
(26.0 \%)\end{array}$ & $\begin{array}{c}19 \\
(38.0 \%)\end{array}$ & $\begin{array}{c}14 \\
(26.0 \%)\end{array}$ & $\begin{array}{c}11 \\
(22.0 \%)\end{array}$ \\
\hline 3 & Ren & $\begin{array}{c}26 \\
(52.0 \%)\end{array}$ & $\begin{array}{c}4 \\
(8.0 \%)\end{array}$ & $\begin{array}{c}24 \\
(58.0 \%)\end{array}$ & $\begin{array}{c}31 \\
(66.0 \%)\end{array}$ \\
\hline
\end{tabular}

Tabel 4 diatas menunjukkan peningkatan minat perawat pasca sosialisasi bagan Pareto, dari kategori 
sedang $(\mathrm{n}=13,26.0 \%)$ menjadi tinggi $(\mathrm{n}=27$, $54.0 \%)$.

\section{Hasil Pengukuran Sosialisasi Diagram Pareto Dalam Peningkatan Pengetahuan Perawat Terhadap Pengelolaan Bahan Habis Pakai}

Hasil pengukuran sosialisasi Pareto terhadap minat perawat dalam pengelolaan bahan habis pakai tersaji pada tabel 5 .

Tabel 5. Pengaruh Sosialisasi Bagan Pareto Dalam Peningkatan Minat Perawat Terhadap Pengelolaan Bahan Habis Pakai

\begin{tabular}{clccc}
\hline No. & Group & Mean & SD & p-value \\
\hline 1 & Intervention & 1.44 & 0.577 & \multirow{2}{*}{0.030} \\
2 & Control & 2.54 & 0.706 & \\
\hline
\end{tabular}

Pada tabel 5 di atas, hasil uji statistik dengan Correlation Pearson menunjukkan bahwa sosialisasi diagram Pareto berpengaruh dalam meningkatkan minat perawat tentang pengelolaan bahan habis pakai di RSUD Simeulue dengan nilai $\mathrm{p}=$ 0,030 ( $p$ value $<0,05$ )

\section{B. Pembahasan}

Lancarnya siklus logistik di sebuah perusahaan ditentukan oleh pengetahuan dan minat karyawannya dalam menjalankan pengelolaan bahan habis pakai. Pengetahuan dan minat yang kurang dari karyawan dalam menjalankan pengelolaan bahan habis pakai disebabkan karena minimnya fasilitas, kurangnya kesadaran tentang pentingnya bahan habis pakai, dan menganggap jika bahan habis pakai bukan tanggung jawab perawat (Honda et al., 2018). Untuk menyikapi hal tersebut, bagian gugus kendali mutu dan pihak manajemen logistik harus mengadakan sosialisasi atau pelatihan secara berkala guna meningkatkan pengetahuan dan minat dari perawat yang mayoritas menggunakan alat medis habis pakai (Chang et al., 2013).

Menjawab masalah pengetahuan dan minat dari perawat yang kurang dalam mengelola bahan habis pakai dalam hal menjalankan siklus logistik di rumah sakit, dibutuhkan semua pihak yang relevan seperti dinas kesehatan, pihak rumah sakit, gugus kendali mutu, manajemen logistik, hingga ke unsur terkecil yakni kepala ruangan, yang memiliki andil untuk menciptakan lingkungan kerja yang kondusif, edukatif, serta memberikan kesempatan kepada para karyawan untuk meningkatkan pengetahuan, guna memberikan minat yang besar untuk mengelola bahan habis pakai yang menjadikan keuntungan kepada pihak rumah sakit (Liu et al., 2016).

Berdasarkan hasil penelitian yang dilakukan, responden berumur 35-40 tahun dan $>40$ tahun yang dikategorikan sebagai perawat memiliki pengetahuan yang kurang terkait pengelolaan bahan habis pakai, yang dapat dikategorikan sebagai umur yang sudah tidak lagi fokus terhadap berbagai pekerjaan yang menuntutnya. Menurut Kulkarni et al. (2018), umur memengaruhi pengetahuan seseorang, karena bertambahnya umur mengubah aspek psikologis. Dalam temuan penelitian ini juga dijelaskan bahwa responden yang memiliki riwayat pekerjaan $>13$ tahun memiliki pengetahuan yang cenderung lebih baik dibandingkan dengan yang memiliki pengalaman bekerja 1-3 tahun. Hal tersebut selaras dengan yang diungkapkan oleh Wirawan (2014), bahwa pengetahuan juga dipengaruhi oleh pengalaman sebelumnya sehingga ada kecenderungan bahwa pengetahuan seseorang meningkat jika telah memiliki pengalaman yang cukup.

Hal lain yang terdapat dalam temuan penelitian ini adalah latar belakang pendidikan dan status pekerjaan merupakan salah satu unsur yang membuat pengetahuan dan minat perawat yang rendah dalam hal mengelola bahan habis pakai. Hal serupa juga dijelaskan oleh Varsha \& Shinde 
(2013) yang menjelaskan bahwa pendidikan, lingkungan, status pekerjaan, budaya, informasi, adalah faktor-faktor yang memengaruhi pengetahuan dan minat seseorang. Faktor lain yang memengaruhi seseorang dalam peningkatan pengetahuan dan minat seserorang dalam hal tindakan adalah faktor internal. Rumah sakit sudah selayaknya memberikan akses yang lebih dalam hal memperbaharui ilmu para perawat. Program sosialisasi atau pelatihan secara berkala diharapkan dapat meningkatkan pengetahuan dan minat perawat terkait pengelolaan bahan habis pakai.

Menurut penelitian yang dilakukan oleh Obolewicz \& Dąbrowski (2018), tugas perawat tidak hanya memberikan asuhan kepada pasien saja, tetapi juga harus memiliki modal ilmu dalam bidang manajemen mutu dan logistik di rumah sakit. Hal senada juga di jelaskan oleh Mureșan et al. (2019) bahwa pihak manajemen RS memiliki andil khusus untuk memberikan pelatihan atau sosialisasi kepada perawat untuk memberikan tambahan ilmu yang berguna untuk peningkatan kualitas staf di rumah sakit.

Hal lain terkait dengan penelitian ini adalah pengetahuan dan minat yang posisif ditandai dengan meningkatnya pengetahuan perawat dalam hal megelola bahan habis pakai dan meningkatnya minat perawat dalam hal mempelajari bahan habis pakai, hal tersebut dikarenakan efek positif dari pemberian sosialisasi yang diberikan. Hal serupa juga diungkapkan oleh Belkasseh (2019) yang menjelaskan bahwa pemberian pelatihan atau sosialisasi yang tepat dan rutin, akan memberikan dampak positif kepada karyawan. Sosialisasi atau pelatihan yang diberikan dianggap sebagai ilmu baru yang memberikan rangsangan baru untuk mempelajarinya.

Sikap adalah pengetahuan disertai dengan minat untuk bertindak (AlKuwaiti \& Maruthamuthu, 2016). Berdasarkan analisis data, lebih dari $50 \%$ perawat memiliki skor tinggi dalam pengetahuan. Hal tersebut sejalan dengan yang diungkapkan oleh Jiang \& Zhou (2012) bahwa yang menentukan minat, pengetahuan sangatlah berperan penting. Dengan pengetahuan, manusia dapat mengembangkan apa yang mereka ketahui dan bisa menerapkan apa yang telah mereka pelajari sehingga dapat memberikan efek positif kepada lingkungan sekitarnya. Menurut Yang et al. (2016), pengetahuan dan minat perawat yang telah diberikan sosialisasi akan berpengaruh kepada pekerjaan, penggunaan alat medis yang prioritas, pembukuan yang lebih rapi, sehingga memberikan keuntungan finansial kepada rumah sakit.

\section{PENUTUP}

\section{A. Kesimpulan}

Hasil penelitian ini ditemukan bahwa sosialisasi diagram Pareto memiliki pengaruh yang signifikan terhadap pengetahuan dan minat perawat dalam pengelolaan bahan habis pakai di rumah sakit.

\section{B. Saran}

Untuk penelitian selanjutnya diharapkan memberikan teknik pelatihan dengan penggabungan dua alat ukur mutu yaitu diagram Pareto dan diagram Fishbhone untuk pengelolaan bahan habis pakai. Hal tersebut berguna untuk melihat hasil yang lebih maksimal terhadap kedua alat ukur mutu tersebut.

\section{UCAPAN TERIMA KASIH}

Ucapan terimakasih kepada drg. Farhan sebagai Direktur Rumah Sakit Umum Daerah Kabupaten Simeulue yang telah memfasilitasi penelitian ini. Dan terimakasih kepada Bapak Setiawan, S.Kp.,MNS.,Ph.D, sebagai Dekan Fakultas 
Keperawatan Universitas Sumatera Utara yang telah memberikan ijin untuk penelitian ini.

\section{DAFTAR PUSTAKA}

Ahmad, M. F., Nee, P. S., Nor, N. H. M., Wei, C. S., Hassan, M. F., \& Hamid, N. A. A. (2017). Total quality management practices in Malaysia healthcare industry. 020021. https:// doi.org/10.1063/1.5005354

Ahmed, M., \& Ahmad, N. (2011). An Application of Pareto Analysis and Cause-and-Effect Diagram (CED) for Minimizing Rejection of Raw Materials in Lamp Production Process. CSCanada Management Science and Engineering, 5(3). https://doi.org/ http://dx.doi.org/10.3968/j.mse. 1913035X20110503.320

Al-Shdaifat, E. A. (2015). Implementation of total quality management in hospitals. Journal of Taibah University Medical Sciences, 10(4), 461-466. https:// doi.org/10.1016/j.jtumed.2015.05.004

AlKuwaiti, A., \& Maruthamuthu, T. (2016). A Model for Performance Measurement and Improvement Related to the Usage of Seven Basic Quality Tools: A Roadmap for Healthcare Performance. Health Care Academician Journal, 3(3), 111. https:// doi.org/10.5455/sad.13-1481449676

Alolayyan, M. N., Ali, K. A. M., \& Idris, F. (2011). The influence of total quality management (TQM) on operational flexibility in Jordanian hospitals. Asian Journal on Quality, 12(2), 204$222 . \quad$ https://doi.org/ 10.1108/15982681111158751

Balasubramanian, M. (2016). Total Quality Management [TQM] in the Healthcare Industry - Challenges, Barriers and Implementation Developing a Framework for TQM Implementation in a Healthcare Setup. Science Journal of Public Health, 4(4), 271. https:// doi.org/10.11648/j.sjph.20160404.11

Belkasseh, M. (2019). The Relationship between Total Quality Management and Financial Performance : Evidence from Morocco. Archives of Business Research, 7(5). https://doi.org/10.14738/ abr.75.6533

Budhiarta, I., \& Samuthi, M. (2019). Pengukuran Kualitas Pelayanan Rumah Sakit di Aceh dengan Model HSQ-Metrix. Jurnal Maksipreneur: Manajemen, Koperasi, Dan Entrepreneurship, 8(2), 154. https:// doi.org/10.30588/jmp.v8i2.412

Chang, C.-S., Chen, S.-Y., \& Lan, Y.-T. (2013). Service quality, trust, and patient satisfaction in interpersonalbased medical service encounters. BMC Health Services Research, 13(1), 22. https://doi.org/10.1186/1472-696313-22

Dahlgaard, J. J., Pettersen, J., \& DahlgaardPark, S. M. (2011). Quality and lean health care: A system for assessing and improving the health of healthcare organisations. Total Quality Management $\mathcal{E}$ Business Excellence, 22(6), 673-689. https://doi.org/ 10.1080/14783363.2011.580651

El-Tohamy, A. E.-M. A., \& Raoush, A. T. Al. (2015). The Impact of Applying Total Quality Management Principles on the Overall Hospital Effectiveness: An Empirical Study on the HCAC Accredited Governmental Hospitals in Jordan. European Scientific Journal, 11(10). https://eujournal.org/ index.php/esj/article/view/5409

Furterer, S. L. (2014). Lean Six Sigma Case Studies in the Healthcare Enterprise. Springer London. https://doi.org/ 10.1007/978-1-4471-5583-6

Hani, U., Basri, M. H., \& Winarso, D. (2013). Inventory Management of Medical Consumables in Public Hospital: a case study. Scientific $\mathcal{E}$ Academic Publishing, 3(2), 128-133. https://doi.org/10.5923/j.mm. 20130302.10

Honda, A. C., Bernardo, V. Z., Gerolamo, M. C., \& Davis, M. M. (2018). How 
Lean Six Sigma Principles Improve Hospital Performance. Quality Management Journal, 25(2), 70-82. https://doi.org/

10.1080/10686967.2018.1436349

Ismariati, I., Samsualam, S., \& Haeruddin, H. (2017). Analisis Sistem Pengendalian Logistik Barang Non Medik Di Rumah Sakit Umum Lasinrang Kab. Pinrang. Jurnal Ilmiah Kesehatan Diagnosis, 11(3), 314-318. http://ejournal.stikesnh.ac.id/ index.php/jikd/article/view/771

Jiang, Y., \& Zhou, L. (2012). Analysis and Design of Third-Party Logistics Information System. In Lecture Notes in Electrical Engineering (pp. 297-305). Springer Berlin Heidelberg. https:// doi.org/10.1007/978-3-642-31003-4_38

Kulkarni, S., Ramesh, R., Srinivasan, A. R., \& Silvia, C. R. W. D. (2018). Evaluation of Preanalytical Quality Indicators by Six Sigma and Pareto`s Principle. Indian Journal of Clinical Biochemistry, 33(1), 102-107. https:// doi.org/10.1007/s12291-017-0654-5

Lin, Z., Jiang, C., Gao, L., \& Xu, H. (2010). Research on Collaborative Optimization of Drug Logistics Company and Hospital based on Value-Added Services under New Medical Reform. The 4th International Conference on Operations and Supply Chain Management, 220-223. http:// gebrc.nccu.edu.tw/proceedings/ APDSI/2010/papers/f049.pdf

Liu, T., Shen, A., Hu, X., Tong, G., Gu, W., \& Yang, S. (2016). SPD-based Logistics Management Model of Medical Consumables in Hospitals. Iranian Journal of Public Health, 45(10), 12881299. http://www.ncbi.nlm.nih.gov/ pubmed/27957435

Manurung, J. M. (2017). Kajian Implementasi Mutu dengan Pendekatan Integrasi Six Sigma dan TQM Melalui Penilaian Malcolm Baldridge di Rumah Sakit Charitas. Jurnal Administrasi Rumah Sakit
Indonesia, 3(2). http://dx.doi.org/ 10.7454/arsi.v3i2.2218

Mureșan, P. I., Miloșan, I., Senchetru, D., Reit, A. N., Machedon, T. P., \& Oancea, G. (2019). Study of health and safety in the manufacturing industry using Pareto analysis. MATEC Web of Conferences, 299, 05008. https://doi.org/ 10.1051/matecconf/201929905008

Obolewicz, J., \& Dąbrowski, A. (2018). An application of the Pareto method in surveys to diagnose managers' and workers' perception of occupational safety and health on selected Polish construction sites. International Journal of Occupational Safety and Ergonomics, 24(3), 406-421. https://doi.org/ 10.1080/10803548.2017.1375781

Parand, A., Dopson, S., Renz, A., \& Vincent, C. (2014). The role of hospital managers in quality and patient safety: a systematic review. BMJ Open, 4(9), e005055-e005055. https:// doi.org/10.1136/bmjopen-2014-005055

Rabou, F. M. E. A., Saad, H. A., \& Ella, S. M. A. El. (2017). Interdisciplinary Collaboration for Investigating Medication Errors Causes: Six Sigma Methodologies. IOSR Journal of Nursing and Health Science, 6(3), 50-58. https://doi.org/10.9790/19590603065058

Sweis, R. J., Mansour, A. Al, Tarawneh, M., \& Dweik, G. Al. (2013). The impact of total quality management practices on employee empowerment in the healthcare sector in Saudi Arabia: a study of King Khalid Hospital. International Journal of Productivity and Quality Management, 12(3), 271-286. https://doi.org/10.1504/ IJPQM.2013.056149

Varsha M, M., \& Shinde, D. V. B. (2013). Enhancement of Quality of the Processes Using Statistical Tools- a Review. International Journal of Engineering Research and General Science, 2(4), 364-371.

Wirawan, G. (2014). Analisis Pengelolaan 
Pengaruh Sosialisasi Diagram Pareto Terhadap Pengetahuan...

Logistik Non Medis di Gudang RSPAU dr. S. Hardjolukito Yogyakarta. Prima Ekonomika: Jurnal Ekonomi Dan Bisnis, 5(1). http:// jurnal.stieykp.ac.id/index.php/primaekonomika/article/view/36

Yang, C., Gu, W., \& Liu, T. (2019). Application and Evaluation of SPD Based Logistics Management Model for Medical Consumables in Clinical Nursing Departments. Iranian Journal of Public Health, 48(8), 1452-1460. https://doi.org/10.18502/

ijph.v48i8.2985

Yang, C., Zhang, W., Gu, W., \& Shen, A. (2016). [Research on the Application of Lean Management in Medical Consumables Material Logistics Management]. Zhongguo Yi Liao Qi Xie $\mathrm{Za} Z \mathrm{Zhi}=$ Chinese Journal of Medical Instrumentation, 40(6), 454-457. http:// www.ncbi.nlm.nih.gov/pubmed/ 29792613

Zhang, X., Luan, W., \& Cai, Q. (2013). A Study on the Performance Evaluation of Third-Party Logistics Enterprises Based on DEA. In LISS 2012: Proceedings of 2nd International Conference on Logistics, Informatics and Service Science (pp. 373-378). Springer Berlin Heidelberg. https://doi.org/ 10.1007/978-3-642-32054-5_54 